Check for updates

Cite this: RSC Adv., 2017, 7, 43310

Received 16th July 2017

Accepted 31st August 2017

DOI: $10.1039 / c 7 r a 07809 a$

rsc.li/rsc-advances

\section{Isotope geochemistry, hydrochemistry, and mineralogy of a river affected by acid mine drainage in a mining area, South China $\dagger$}

\author{
Di Xia, ${ }^{a}$ Han Ye, ${ }^{a}$ Yingying Xie, ${ }^{a}$ Chengfang Yang, ${ }^{a}$ Meiqin Chen, ${ }^{b}$ Zhi Dang, ${ }^{\text {ac }}$ \\ Xiaoyun $\mathrm{Yi}^{\mathrm{ac}}$ and Guining Lu (iD) *ad
}

The Hengshi River is a classic example of an acid mine drainage (AMD)-affected river located in the Dabaoshan mining area in southern China. This work utilized stable isotopes $\left(\delta^{34} \mathrm{~S}\right.$ and $\left.\delta^{18} \mathrm{O}\right)$ and hydrochemical data of surface water samples as well as the mineralogical composition of sediment samples to evaluate the processes that affect the sulfate content in water of the Hengshi River. High concentrations of heavy metals (e.g. Fe: $>347.78 \mathrm{mg} \mathrm{L}^{-1} ; \mathrm{Zn}$ : $>96.48 \mathrm{mg} \mathrm{L}^{-1}$ ) in the mud impoundment and relatively stable $\mathrm{S}$ isotope values $\left(\delta^{34} \mathrm{~S}:-1.53 \% \sim-0.88 \%\right)$ in the upper stream suggested that most of the sulfates were derived from sulfide oxidation. Dilution and mineralization could decrease $\mathrm{SO}_{4}{ }^{2-}$ concentration, but had no significant influence on the isotope composition of $\mathrm{SO}_{4}{ }^{2-}$. However, $\delta^{34} \mathrm{~S}$ and $\delta^{18} \mathrm{O}$ increased with the decrease of $\mathrm{SO}_{4}{ }^{2-}$ concentration, accompanied by the elevation of $\mathrm{pH}$ and adequate organic matter being available, suggesting that bacterial (dissimilatory) sulfate reduction played an important role in the transformation of sulfate downstream. The methods used in this study can also be used in other natural systems. Furthermore, it is important to understand the causes of environmental pollution and to help environmental remediation.

\section{Introduction}

Mining activity is a main source of hazardous elements and can produce acid mine drainage (AMD), which poses a major threat to the surrounding environment and human health., ${ }^{1,2}$ Sulfate is an essential component in AMD whose transformation plays a key role in the hydrochemical development of rivers in mining areas. $^{3-5}$ Sulfate is predominantly caused by the oxidation of pyrite, accompanied by the liberation of acid, and metals. ${ }^{6-8}$ Pyrite can be oxidized by dissolved molecular oxygen and ferric iron. Pyrite oxidation by $\mathrm{Fe}^{3+}$ has been shown to be 18 to 170 times more rapidly than by $\mathrm{O}_{2} \cdot{ }^{9}$ However, this step is limited by the rate of ferrous iron oxidation. The slow abiotic reaction which produces ferric iron can be catalyzed primarily by $\mathrm{Fe}$ -

${ }^{a}$ School of Environment and Energy, South China University of Technology, Guangzhou 510006, China. E-mail: GNLu@foxmail.com

${ }^{b}$ School of Environmental and Biological Engineering, Guangdong University of Petrochemical Technology, Maoming 525000, China

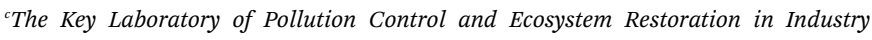
Clusters, Ministry of Education, South China University of Technology, Guangzhou 510006, China

${ }^{d}$ Guangdong Provincial Engineering and Technology Research Center for Environmental Risk Prevention and Emergency Disposal, South China University of Technology, Guangzhou 510006, China

$\dagger$ Electronic supplementary information (ESI) available. See DOI: $10.1039 / \mathrm{c} 7 \mathrm{ra} 07809 \mathrm{a}$ oxidizing bacteria like Acidithiobacillus ferrooxidans and Acidithiobacillus thiooxidans. ${ }^{\mathbf{1 0 , 1 1}}$

Bacterial (dissimilatory) sulfate reduction (BSR) is an invertible process that can produce alkalinity and generate iron sulphide minerals, ${ }^{12-15}$ thereby potentially resulting in an effective neutralization of the river affected by AMD. Sulfate reducing bacteria are anaerobes, which prefer anaerobic environment with sufficient availability of organic matter. ${ }^{16,17}$ So BSR is often occurring in sediments, but it also can occur in the water column and the water-sediment interface. ${ }^{18}$ In AMD area, BSR often occurs in association with microbial ferric reduction. ${ }^{19-21}$ And the reaction can be summarized in the eqn (1): ${ }^{22}$

$$
\begin{aligned}
& 15\left\langle\mathrm{CH}_{2} \mathrm{O}\right\rangle+6 \mathrm{FeOOH}+7 \mathrm{SO}_{4}{ }^{2-}+14 \mathrm{H}^{+} \rightarrow \\
& 15 \mathrm{CO}_{2}+6 \mathrm{FeS}+\mathrm{S}^{(0)}+25 \mathrm{H}_{2} \mathrm{O}
\end{aligned}
$$

Sulfur and oxygen isotopes are powerful tools to track $\mathrm{SO}_{4}{ }^{2-}$ sources and assess S cycling in watersheds. According to field samples and experimental studies, ${ }^{2-25}$ the sulfur isotope composition of sulfate is very close to its major bedrock sources of S (like sulfides, evaporates, etc.) participating in water-rock interaction. But the oxygen isotope composition of sulfate can be affected by the oxidation mechanisms because of the difference between the oxygen isotopic composition of water $\left(\delta^{18} \mathrm{O}\right.$ generally $<0 \%$ ond atmospheric oxygen $\left(\delta^{18} \mathrm{O}=23.5 \pm\right.$ $0.3 \%$ (ref. 26)). Once formed, the sulfur and oxygen isotopic composition of sulfate tends to remain stable, because the 
isotopic exchange between water and sulfate is slow (360 years at pH 1.0 and $\left.25{ }^{\circ} \mathrm{C}\right) .{ }^{27,28}$ However, BSR is a complex process which involves large kinetic fractionation effects on both sulphur and oxygen isotopes. ${ }^{29-31}$ During the BSR, bacteria preferentially break ${ }^{32} \mathrm{~S}$ and ${ }^{16} \mathrm{O}$ containing bonds and the residual dissolved sulfate becomes isotopically enriched in ${ }^{34} \mathrm{~S}$ and ${ }^{18} \mathrm{O} .{ }^{32-34}$ Therefore, the sulfur and oxygen isotope ratio of sulfate combined with their physical and chemical properties could be useful to identify bacterial reduction processes.

Even though there has been a great deal of work focused on the species distribution, migration and transformation in the water of AMD-affected river, ${ }^{35-43}$ less attention has been paid to identify the source of sulfate. Thus, by means of characterizing water and sediments from Hengshi River affected by the AMD, the major objectives of this study are: (1) to identify the sources of dissolved sulfate; (2) to evaluate the processes that control spatial variation of concentrations and isotope compositions of dissolve $\mathrm{SO}_{4}{ }^{2-}$ along the Hengshi River.

\section{Materials and methods}

\subsection{Study site}

The study site (Fig. 1) is located at the Dabaoshan Mining area $\left(24^{\circ} 34^{\prime} 28^{\prime \prime} \mathrm{N}, 113^{\circ} 43^{\prime} 42^{\prime \prime} \mathrm{E}\right)$ near the largest poly-metallic sulfide mine of Guangdong Province in southern China. ${ }^{44,45}$ Because of the mining activities for many years, there are large amounts of mining wastes left on the land surface. These wastes contain large amounts of sulfide minerals. The sulfide minerals could be oxidized and leading to the formation of AMD, which formed an acidic reservoir intercepted by a dam wall. ${ }^{46}$ The water of the reservoir contains high concentrations of sulfate (>4008.04 $\mathrm{mg} \mathrm{L}^{-1}$ ) and iron (>347.78 $\mathrm{mg} \mathrm{L}^{-1}$ ) with low $\mathrm{pH}$ values $(<2.98)$ during the investigation period. With the accumulation of water and sediments, the reservoir was rapidly filled up, and then the acidic water continuously flowed into the Hengshi River for years. The Hengshi River runs through Shangba Village and Wengcheng Town, joined by several tributaries, including the Lengshui River, the Fanshui River and the Taiping River, and enters into the Wengjiang River finally. It's worth noting that a sewage treatment plant was built in $2.5 \mathrm{~km}$ downstream (S2) from the dam after January 2016, in order to control the pollution.

\subsection{Sampling and pretreatment}

In January, August and November of 2016, surface water and sediment samples were collected from these sites of Hengshi River (Fig. 1), the same with the previous studied sites in our group. ${ }^{47} \mathrm{~S} 1 \sim \mathrm{S} 11$ were set along the Hengshi River, from the river's headwaters (S1) to the Wengjiang River (S11). S0 represents the acidic lake of the mud impoundment. S8 and S9 are close to the residential area of Shangba Village and Wengcheng Town, respectively. In August 2016, we found that there were some domestic sewage from Shangba Village flowed into the Hengshi River in S8, which was observed only in this season. It was a pity that we didn't collect the samples of $\mathrm{S} 2$ because the sewage treatment plant covered S2. Also we didn't get the samples of S5 and C2 in August due to the geography changing.

In addition, C1, C2, C3 and TP served as control sites which were located in the four major tributaries, including Lengshui, Fanshui, Wengjiang and Taiping Rivers respectively. These tributaries flowed to Hengshi River. The Lengshui River and Taiping River were unpolluted, but the water of C2 also had been polluted by the AMD from the tailing impoundment.

In all locations, the water samples were filtered in the field with a $0.22 \mu \mathrm{m}$ nylon syringe filter into $15 \mathrm{~mL}$ centrifuge tubes. One portion of water was acidified with $1 \mathrm{~mL} 3 \mathrm{~N} \mathrm{HCl}$ to analyze

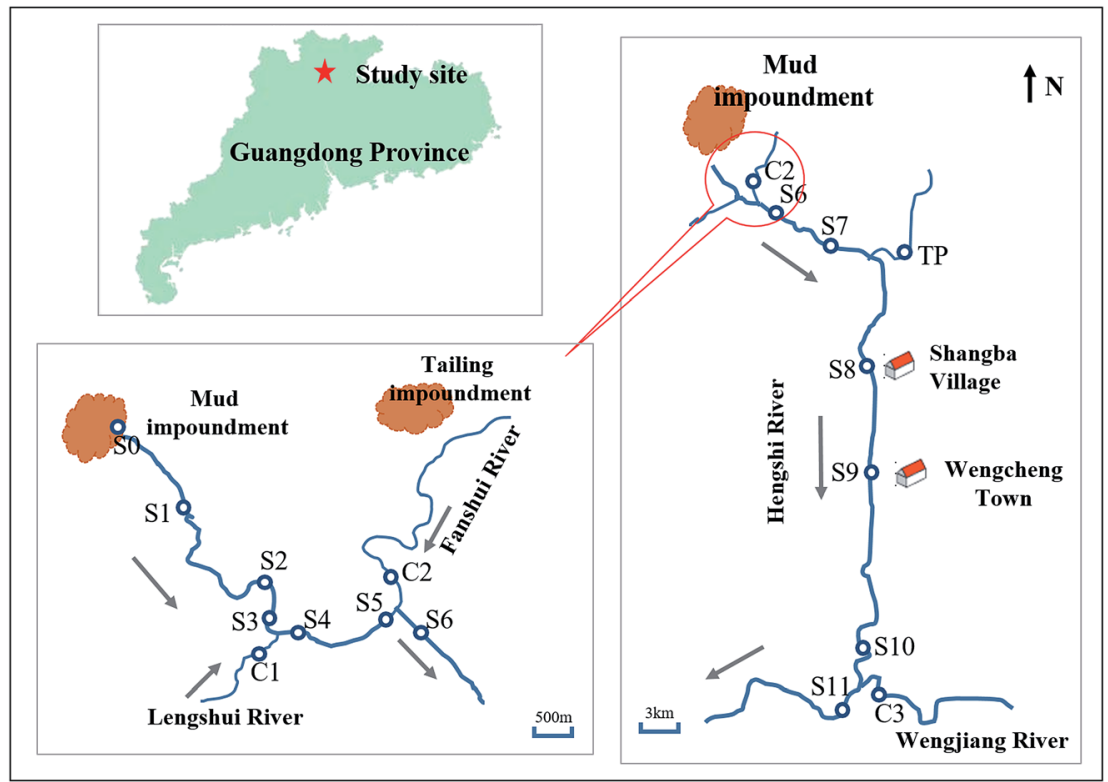

Fig. 1 Location and sampling sites of this study along the Hengshi River in the Dabaoshan mine area in Guangdong Province, China. Blue hollow circles represent the sampling sites. Gray arrows indicate the direction of the river flow. 
$\mathrm{Fe}^{2+}$ concentration. The second portion was acidified with $1 \mathrm{~mL}$ high-purity concentrated $\mathrm{HNO}_{3}$ for cation analysis, and the third portion was left untreated for anion analysis. Unfiltered surface water samples were collected in plastic bottles for $S$ and O isotope analysis. Surface-sediment samples were collected at the same place also using plastic bottles. Each sample was made in triplicate. Water samples were stored at $4{ }^{\circ} \mathrm{C}$ while sediment samples were stored at $-20{ }^{\circ} \mathrm{C}$ before analysis.

\subsection{Chemical analysis}

2.3.1 Water. $\mathrm{pH}$, temperature, oxidation-reduction potential (ORP), and conductivity were measured in situ for surface water using a multi-parameter tester (SG2-T SevenGopro ${ }^{\mathrm{TM}}$ MTD, Switzerland). Dissolved oxygen (DO) was measured by DO meter. The determination of major cations (total Fe, Cu, Zn, Ca and $\mathrm{Mg}$ ) concentration was performed by flame atomic absorption spectrophotometry (Z-2000, Hitachi, Japan). The concentration of $\mathrm{Fe}^{2+}$ were measured by ultraviolet colorimetric assay using the 1,10-phenanthroline spectrophotography method at $510 \mathrm{~nm}$ (UV-2550, SHIMADZU, Japan). Sulfate concentrations were measured by ion chromatography (Dionex1000, Thermo Scientific, USA) with an AG14 anion exchange columns in conjunction with an AS14 separator column to separate the anion species. The mobile phase composition was $3.5 \mathrm{mM} \mathrm{Na} \mathrm{CO}_{3}-1.0 \mathrm{mM} \mathrm{NaHCO}$, delivered at a flow rate of $1.2 \mathrm{~mL} \mathrm{~min}^{-1}$.

2.3.2 Sediments. Before analyses, all sediment samples were centrifuged to remove pore water. Then the samples were dried by vacuum freeze-drying, followed by grounding and sieving by 200 mesh plastic sieves.

$0.5 \mathrm{~g}$ sediment was used for the determination of water soluble sulfate (WS) and exchangeable sulfate (ExS) separately. The sediment extracted by deionized water (sediment : water $=$ $1: 20 \mathrm{w} / \mathrm{w}$ ) was sampled to determine WS and that extracted by phosphate solution (0.032 M sodium dihydrogen phosphate, $\mathrm{pH}$ adjusted to 6) was used to determine ExS. After shaking $\left(150 \mathrm{rpm}, 25^{\circ} \mathrm{C}\right) 2 \mathrm{~h}$, the supernatant was filtered and analyzed about the concentration of $\mathrm{SO}_{4}{ }^{2-}$ by ion chromatography. ${ }^{48,49}$

A semiquantitative estimate of the mineralogical composition of the samples was taken by powder X-ray diffraction (XRD) analysis using a Bruker XRD machine $(\mathrm{Cu}-\mathrm{K} \alpha$ radiation, D8 Advance, Bruker Co. Ltd., Germany). Scan parameters used were $5^{\circ}-80^{\circ} 2 \theta$, with a step size of $0.02^{\circ} 2 \theta$ and $0.1 \mathrm{~s}$ acquisition time.

2.3.3 Isotope analysis. Stable isotope analyses were conducted by an Elemental Analyzer with IsoPrime JB144 (Elementar Co. Ltd., Germany) at the Institute of Geochemistry, Chinese Academy of Sciences in Guizhou Province. Water samples for $\mathrm{S}, \mathrm{O}$ isotope analyses of $\mathrm{SO}_{4}{ }^{2-}$ were filtered with a $0.45 \mu \mathrm{m}$ nylon syringe, acidified with $\mathrm{HCl}$ until $\mathrm{pH}<2$, then precipitated as $\mathrm{BaSO}_{4}$ by adding excessive $10 \% \mathrm{BaCl}_{2}$ solution. After precipitated, $\mathrm{BaSO}_{4}$ were isolated by centrifugation. What' more, the precipitates need to be rinsed several times with deionized water to remove $\mathrm{Cl}^{-}$before drying at $110{ }^{\circ} \mathrm{C}$ for $24 \mathrm{~h}$. According to the eqn (2), $\mathrm{S}$ isotope data were reported with respect to VCDT (Vienna Canon Diablo Troilite) and $\mathrm{O}$ isotope data were determined in parts per thousand $(\%)$ deviation from the composition of Vienna Standard Mean Ocean Water (VSMOW).

$$
\delta(\%)=\left(R_{\text {sample }}-R_{\text {standard }}\right) / R_{\text {standard }} \times 1000
$$

where $R$ is the isotopic ratio of the heavy isotope and the light isotope, like ${ }^{34} \mathrm{~S} /{ }^{32} \mathrm{~S}$ and ${ }^{18} \mathrm{O} /{ }^{16} \mathrm{O}$.

\section{Results and discussion}

\subsection{Water chemistry}

Physicochemical properties of the water at each site are shown in Fig. 2. In January 2016, pH values gradually increased along the Hengshi River (Fig. 2(a)), which was consistent to the previous study. ${ }^{47}$ However, due to the sewage treatment plant built in S2, pH value of S3 was rapidly raised to 9.38 (in August) and 6.95 (in November), respectively. The highest $\mathrm{pH}$ value can reach to 10.3 (in November) in S4, and then gradually decreased to neutral $\mathrm{pH}$ in $\mathrm{S} 11(\mathrm{pH}=7.55)$. The dilution of water by tributaries (C1) and rainfall may result in the decrease of $\mathrm{pH}$ from S4-S7 sites. Phase transformation of metastable secondary minerals in the sediments with the release of $\mathrm{H}^{+}$such as the transformation of schwertmannite to goethite as shown in eqn (3) may also play some roles on the decreased $\mathrm{pH}$ values.

$$
\mathrm{Fe}_{8} \mathrm{O}_{8}(\mathrm{OH})_{6} \mathrm{SO}_{4(\mathrm{~s})}+2 \mathrm{H}_{2} \mathrm{O} \rightarrow 8 \mathrm{FeOOH}_{(\mathrm{s})}+\mathrm{SO}_{4}{ }^{2-}+2 \mathrm{H}^{+}
$$

In January, the ORP (Fig. 2(b)) ranged from +192 to $+442 \mathrm{mV}$ in the Hengshi River, while the value ranged from -86 to +332 mV in November. Changes of ORP was closely connected with $\mathrm{pH}$ changes from January to November. The DO values (Fig. 2(c)) in the Hengshi River were above $3.5 \mathrm{mg} \mathrm{L}^{-1}$, with further elevation in the winter (November).

S1 was seriously polluted by AMD and an area with high concentrations of sulfate $\left(>4008.04 \mathrm{mg} \mathrm{L}^{-1}\right)$ and heavy metals (e.g. $\mathrm{Fe}>347.78 \mathrm{mg} \mathrm{L}^{-1} ; \mathrm{Zn}>96.48 \mathrm{mg} \mathrm{L}^{-1}$ ) (Fig. 3). In all investigated seasons, the concentration of $\mathrm{SO}_{4}{ }^{2-}$ decreased with the increased distance from the headwater region. Concentrations of most of the major cations decreased from the S1 to S11 in January, including total Fe (from 646.13 to $0.10 \mathrm{mg} \mathrm{L}^{-1}$ ), $\mathrm{Zn}$ (from 116.82 to $0.02 \mathrm{mg} \mathrm{L}^{-1}$ ), $\mathrm{Cu}$ (from 11.89 to $0.01 \mathrm{mg} \mathrm{L}^{-1}$ ), $\mathrm{Mg}$ (from 230.54 to $3.11 \mathrm{mg} \mathrm{L}^{-1}$ ), but the concentration of $\mathrm{Ca}$ increased in $\mathrm{S} 3$, which might be attributed to the addition of $\mathrm{CaCO}_{3}$ from the sewage plant. Furthermore, the concentrations of heavy metals decreased to extremely low in S3 (e.g. Fe: $0.21 \mathrm{mg} \mathrm{L}^{-1}$; $\mathrm{Cu}: 0.02 \mathrm{mg} \mathrm{L}^{-1}$; Zn: $0.36 \mathrm{mg} \mathrm{L}^{-1}$ ) of the samples collected in August and November with the elevated pH.

Statistical analysis of surface-water chemistry results (Table 1) confirmed the relationship between sulfide (such as pyrite and sphalerite etc.) oxidation and heavy metals concentrations. High concentrations of $\mathrm{Fe}\left(646.13 \mathrm{mg} \mathrm{L}^{-1}\right)$ and $\mathrm{Zn}\left(128.87 \mathrm{mg} \mathrm{L}^{-1}\right)$ with relatively lower concentrations of $\mathrm{Ca}\left(24.30 \mathrm{mg} \mathrm{L}^{-1}\right)$ in the mud impoundment (S0, data are not shown) suggested that most of the sulfate was derived from sulphide oxidation, rather than the dissolution of sulfate minerals, such as gypsum. ${ }^{51}$ 

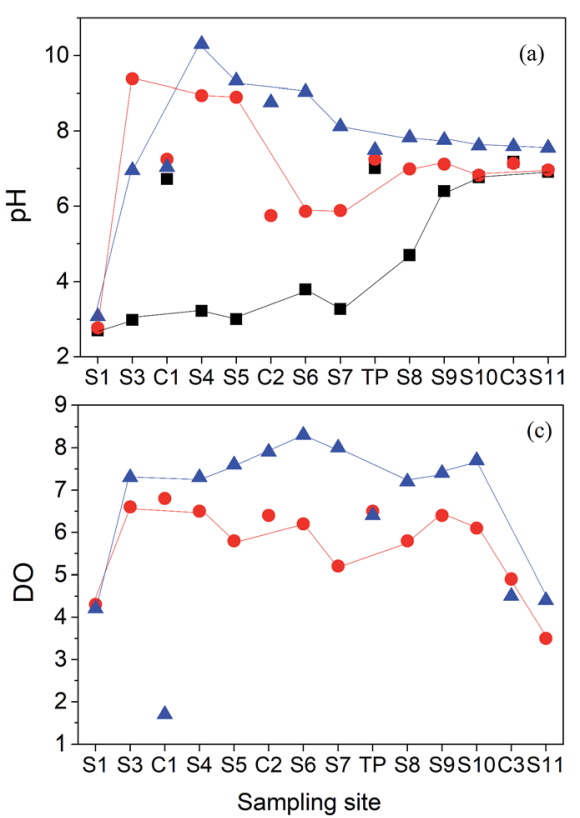

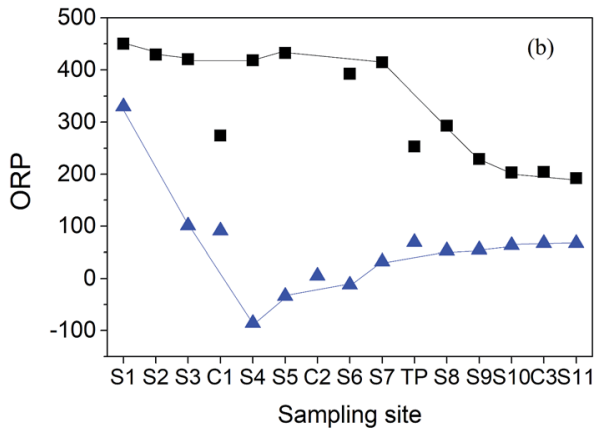

- January

- August

- November

Fig. 2 Aqueous parameters in the Hengshi River (a) pH; (b) ORP and (c) DO in Jan/Aug/Nov 2016.

$\mathrm{pH}$ values are inversely correlated to the concentration of most dissolved metals and $\mathrm{SO}_{4}{ }^{2-}$ (Table 1), indicating the link of sulfuric acid generation and sulfide oxidation. The correlation may due to the $\mathrm{pH}$-dependent complexing of components between the precipitated solid phases and metals dissolved in AMD liquid phases. These components at different $\mathrm{pH}$ may cause $\mathrm{pH}$-induced sorption and/or precipitation reactions and decrease of solubility. ${ }^{2,52}$ The clear positive relationship between heavy metals and $\mathrm{SO}_{4}{ }^{2-}$ may indicate the dominated migration of $\mathrm{SO}_{4}{ }^{2-}$ associated with the co-precipitation of secondary minerals with heavy metals. ${ }^{50}$

\subsection{Sediments chemistry}

As shown in Fig. 4(a), the concentrations of the sediment organic matter (OM) slightly increased along the river.
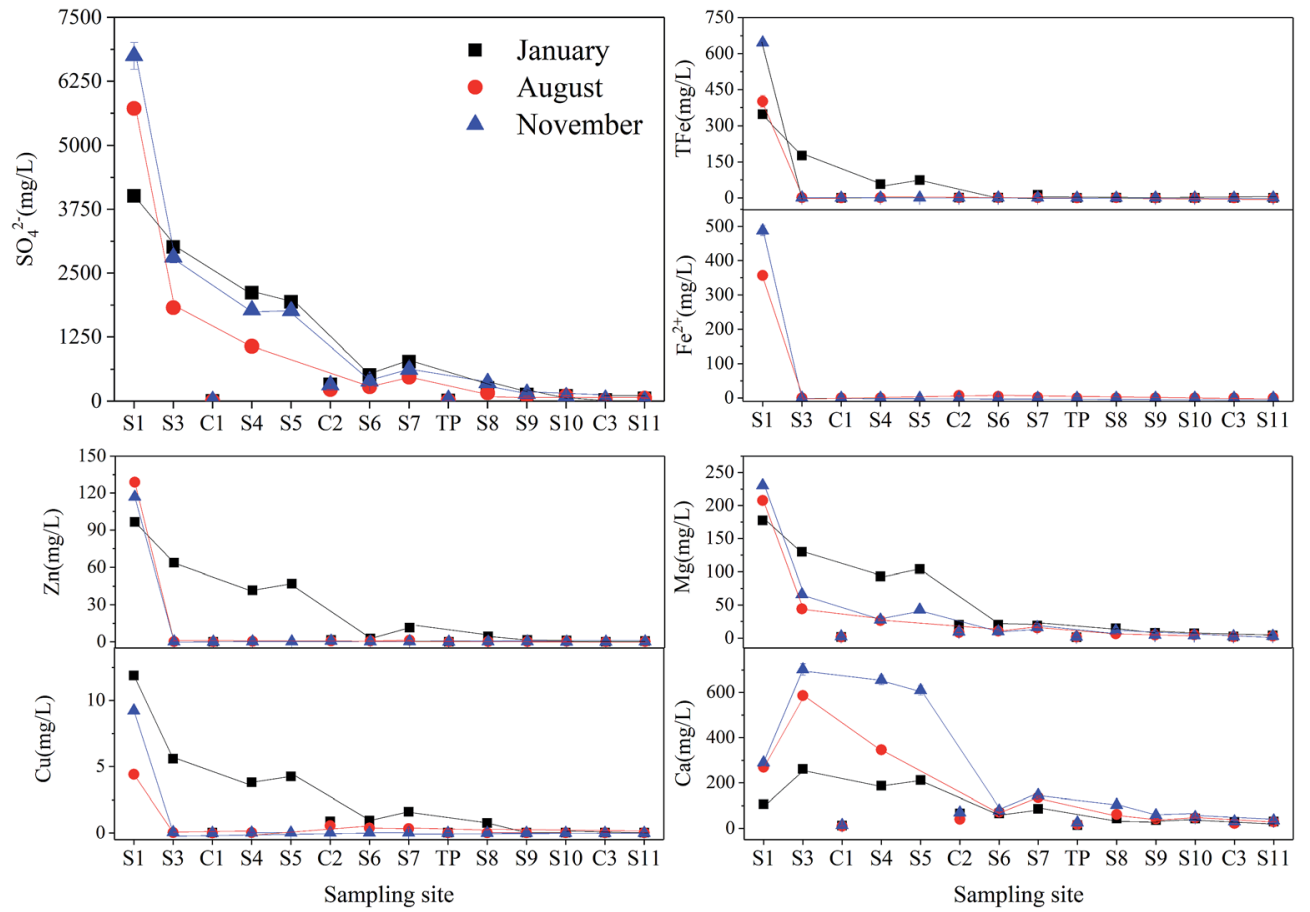

Fig. 3 Concentrations of major ions, including $\mathrm{SO}_{4}{ }^{2-}$, total Fe, $\mathrm{Fe}^{2+}, \mathrm{Zn}, \mathrm{Cu}, \mathrm{Mg}$ and $\mathrm{Ca}$, in Hengshi River in Jan/Aug/Nov 2016. 
Table 1 Correlation analysis results in surface water samples (in bold $p$-value $<0.05$ )

\begin{tabular}{|c|c|c|c|c|c|c|c|c|c|c|c|}
\hline & $\mathrm{pH}$ & ORP & $\delta^{34} \mathrm{~S}$ & $\delta^{18} \mathrm{O}$ & $\mathrm{SO}_{4}{ }^{2-}$ & $\mathrm{Fe}$ & $\mathrm{Cu}$ & $\mathrm{Zn}$ & $\mathrm{Mn}$ & $\mathrm{Ca}$ & $\mathrm{Mg}$ \\
\hline $\mathrm{pH}$ & 1.000 & & & & & & & & & & \\
\hline ORP & -0.957 & 1.000 & & & & & & & & & \\
\hline$\delta^{18} \mathrm{O}$ & 0.657 & -0.676 & 0.889 & 1.000 & & & & & & & \\
\hline $\mathrm{SO}_{4}{ }^{2-}$ & -0.623 & 0.478 & -0.504 & -0.372 & 1.000 & & & & & & \\
\hline $\mathrm{Fe}$ & -0.628 & 0.516 & -0.302 & -0.288 & 0.893 & 1.000 & & & & & \\
\hline $\mathrm{Mn}$ & -0.732 & 0.573 & -0.391 & -0.368 & 0.829 & 0.716 & 0.818 & 0.930 & 1.000 & & \\
\hline $\mathrm{Ca}$ & 0.152 & -0.210 & -0.474 & -0.359 & 0.479 & 0.153 & 0.044 & 0.158 & 0.121 & 1.000 & \\
\hline $\mathrm{Mg}$ & -0.712 & 0.605 & -0.468 & -0.371 & 0.973 & 0.924 & 0.643 & 0.930 & 0.811 & 0.351 & 1.000 \\
\hline
\end{tabular}

Particularly in August, OM increased significantly at S8 due to the addition of the domestic sewage from Shangba Village. Furthermore, the concentrations of OM were always lower in the November than that in the August. Concentrations of WS and ExS at these sites (from S3 to S7) (Fig. 4(b)) changed a lot with the seasonal variation. In August, ExS at S7 reached to $12.93 \mathrm{mg} \mathrm{g}^{-1}$, which can be explained by the formation of secondary minerals like schwertmannite or jarosite. In November, WS and ExS at $\mathrm{S} 4$ increased to 6.63 and $15.96 \mathrm{mg} \mathrm{g}^{-1}$, respectively, which may be a result from the precipitation of gypsum.

XRD results (Fig. 5) indicate that surface sediments at $\mathrm{S} 1, \mathrm{~S} 4$ and S7 were mainly composed of kaolinite, gismondine, quartz and iron oxides (mainly in forms of goethite and ferrihydrite). Schwertmannite were also observed at S7 through SEM analysis, which was corresponding to the high concentration of ExS detected at S7 in August. Similar results were previously divulgated by others authors. ${ }^{53-55}$ The present study helps to demonstrate the importance of geochemistry. Therefore the present study is of great importance for the advancement of science.

\section{3 $S$ and $O$ isotope compositions of dissolved sulfate}

Variations of $\delta^{34} \mathrm{~S}$ and $\delta^{18} \mathrm{O}$ of dissolved $\mathrm{SO}_{4}{ }^{2-}$ along the Hengshi River are shown in Fig. 6. In Jan/Nov/Dec 2016, the $\delta^{34} \mathrm{~S}$ of dissolved $\mathrm{SO}_{4}{ }^{2-}$ in the Hengshi River gradually increased from $-1.23 \%$ to $+1.99 \%$ from the headwater region (S1) to the Wengjiang River (S11). Similarly, $\delta^{18} \mathrm{O}$ values (only in January) of dissolved $\mathrm{SO}_{4}{ }^{2-}$ gradually increased from $-2.66 \%$ to $+4.31 \%$ o along the river. The water of mud impoundment (S0) had the lowest value of $\delta^{34} \mathrm{~S}$ of $-1.53 \%$. Results showed (Fig. 6) the relatively stable values for $\mathrm{S}$ and $\mathrm{O}$ isotope before $\mathrm{S} 8(-1.53 \%$ $-0.88 \%$ and $-3.18 \% \sim-2.68 \%$, respectively) and the increasingly values after S8 $(-0.88 \% \sim+1.99 \%$, and $-2.68 \% \sim$ $+4.31 \%$, respectively). However, there was a slight increase of $\delta^{34} \mathrm{~S}$ at $\mathrm{S} 6$, which may be caused by the heterogeneous mixture of water from $\mathrm{C} 2$ and $\mathrm{S} 5$ because $\mathrm{S} 6$ was sited near the intersection. The collected surface water of $\mathrm{C} 2$, polluted by the AMD from the tailing impoundment, showed similar values $\left(\delta^{34} \mathrm{~S}=\right.$ $-0.44 \%, \delta^{18} \mathrm{O}=-3.97 \%$ ) with observed in the upper stream. Nevertheless, $\mathrm{S}$ isotope values of water collected from the unpolluted river (C1, C3 and TP) were much higher than that collected from the polluted river. One tributary sample (C3) taken in January has a significantly lower concentration of $\delta^{34} \mathrm{~S}$ compared with other samples that were taken from August and November. In addition, other samples did not display any obvious season-related effects.

It is well-known that oxidation of sulfides to $\mathrm{SO}_{4}{ }^{2-}$ is generally accompanied by only a minimal fractionation essentially retaining the original isotopic composition of the sulfide minerals. ${ }^{56}$ Accordingly, the stable values for $\mathrm{S}$ isotope at S0
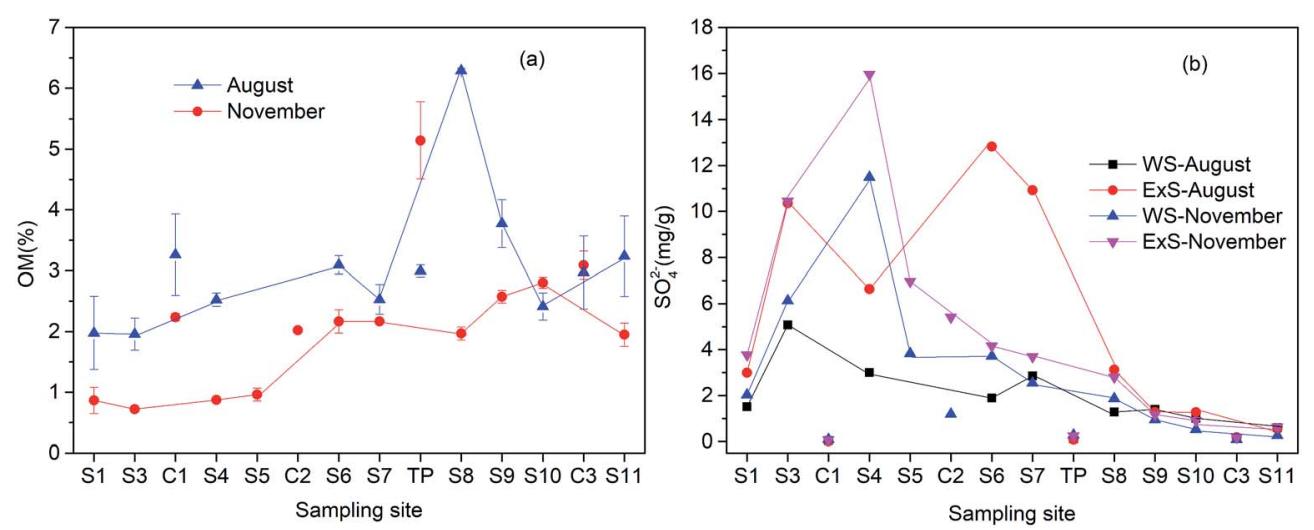

Fig. 4 Concentration distributions of organic matter (OM) (a), water soluble sulfate (WS) and exchangeable sulfate (ExS) (b) in sediment samples along the Hengshi River. 

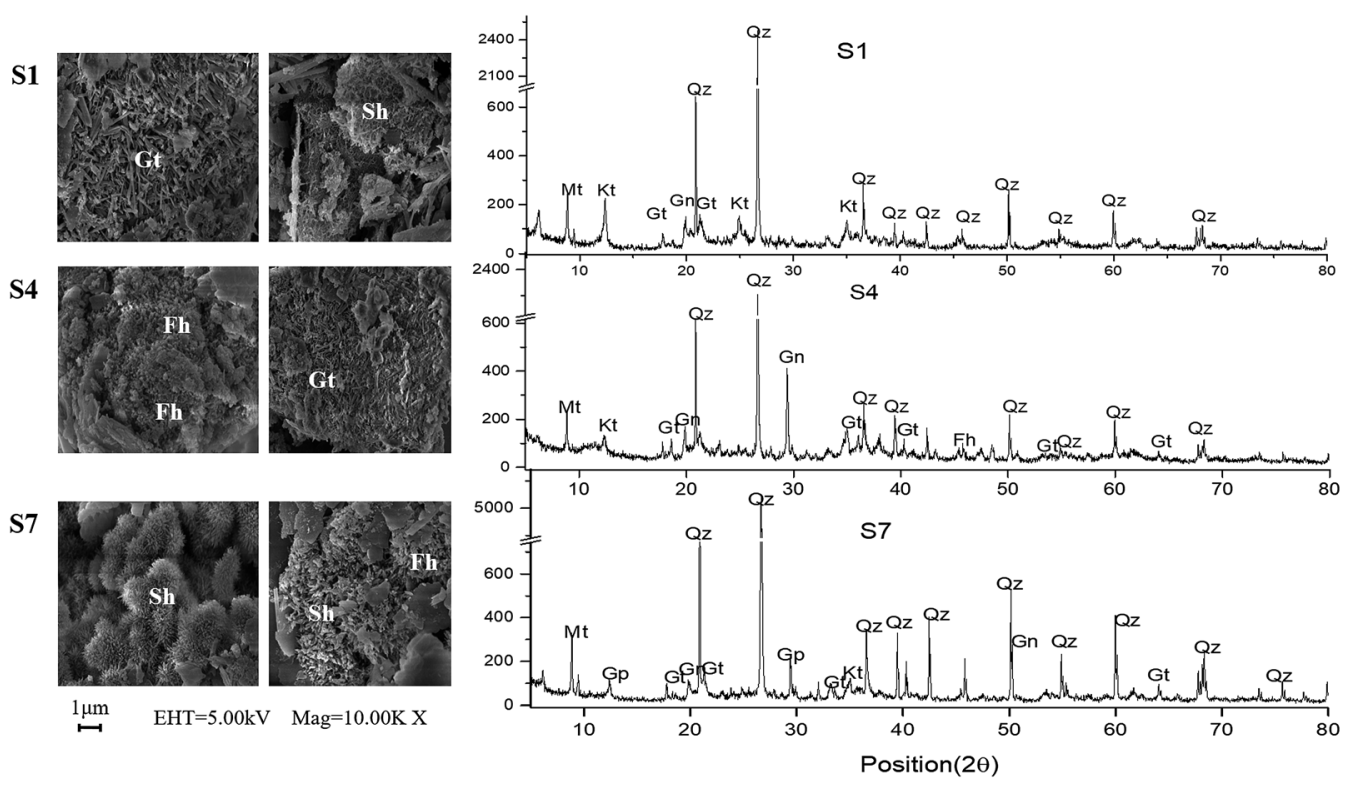

Fig. 5 XRD and SEM of surface sediments in the river in August (Mt - muscovite, Qz - quartz, Kt - kaolinite, Gn - gismondine, Gp - gypsum, Gt - goethite, Sh - schwertmannite, Fh - ferrihydrite).

$(-1.75 \% \sim-1.53 \%)$ may suggested that most sulfate in the upper stream is derived from sulphide oxidation which typically has negative $\delta^{34} \mathrm{~S}$ values. ${ }^{57}$ However, sulfate could also be influenced by other processes, which mainly included: (1) mixing of sulfate resulted from human activities and tributaries, (2) atmospheric deposition, (3) precipitated as secondary mineral, (4) bacterial (dissimilatory) sulfate reduction..$^{58-61}$

3.3.1 Influenced by physiochemical process. Influenced by tributaries (C1) and human activities (especially at S8, where had an abouchement of domestic sewage in August), $\mathrm{SO}_{4}{ }^{2-}$ concentration decreased a lot at $\mathrm{S} 4$ and $\mathrm{S} 8$. However, only small changes in $\delta^{34} \mathrm{~S}$ and $\delta^{18} \mathrm{O}$ values of $\mathrm{SO}_{4}{ }^{2-}$ (Fig. 6) were observed at these two sites, which suggested that dilution had no significant effect on the isotope composition of $\mathrm{SO}_{4}{ }^{2-}$. $\mathrm{SO}_{4}{ }^{2-}$ from atmospheric deposition was often accompanied by the rainfall which was quite different in different seasons. Specifically, $\mathrm{SO}_{4}{ }^{2-}$ concentrations in the dry season (January and
November) were higher than those in the wet season (August). However, no clear distinction of $\delta^{34} \mathrm{~S}$ between the different seasons was obtained, suggesting that atmospheric deposition failed to exert an obvious effect on the $\delta^{34} \mathrm{~S}$ values. It may only have a dilution effect. Sulfate levels decline sharply in river and high content of ExS precipitated as secondary mineral at S4 and S7. But the similar $\delta^{34} \mathrm{~S}$ and $\delta^{18} \mathrm{O}$ of $\mathrm{SO}_{4}{ }^{2-}$ before $\mathrm{S} 8$ seems to suggest that only minor fractionation of either sulfur or oxygen isotopes was produced during precipitation and/or dissolution of $\mathrm{SO}_{4}{ }^{2-}$ minerals.

3.3.2 Influenced by biological process. Generally, bacteria prefer to metabolize ${ }^{32} \mathrm{~S}$ compared with ${ }^{34} \mathrm{~S}$, resulting in progressively more enriched ${ }^{34} \mathrm{~S}$ in remaining sulfate with the sulfate concentrations decrease. ${ }^{62,63}$ As seen in Fig. 7(a), the $\delta^{34} \mathrm{~S}$ and $\delta^{18} \mathrm{O}$ indeed increased with decreasing $\mathrm{SO}_{4}{ }^{2-}$ concentrations along the Hengshi River. Moreover, the plot of $\delta^{18} \mathrm{O}$ versus $\delta^{34} \mathrm{~S}$ (Fig. 7(b)) showed a positive correlation of sulfur and oxygen isotope ratios. Samples collected in the upper stream
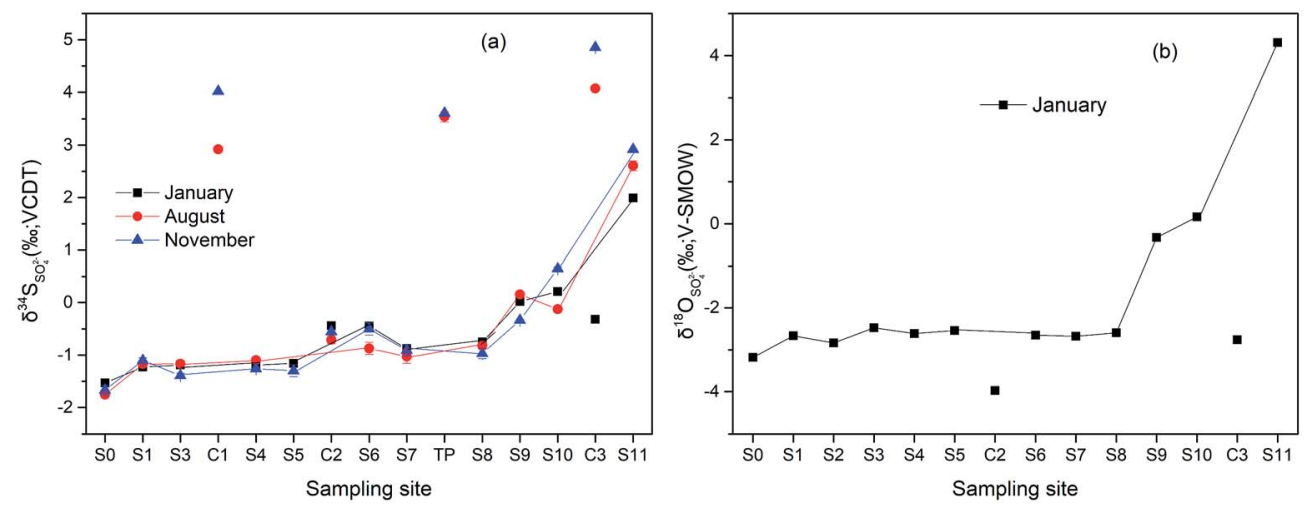

Fig. 6 Variations of $\delta^{34} \mathrm{~S}(\mathrm{a})$ and $\delta^{18} \mathrm{O}$ (b) of dissolved $\mathrm{SO}_{4}{ }^{2-}$ along the Hengshi River. 


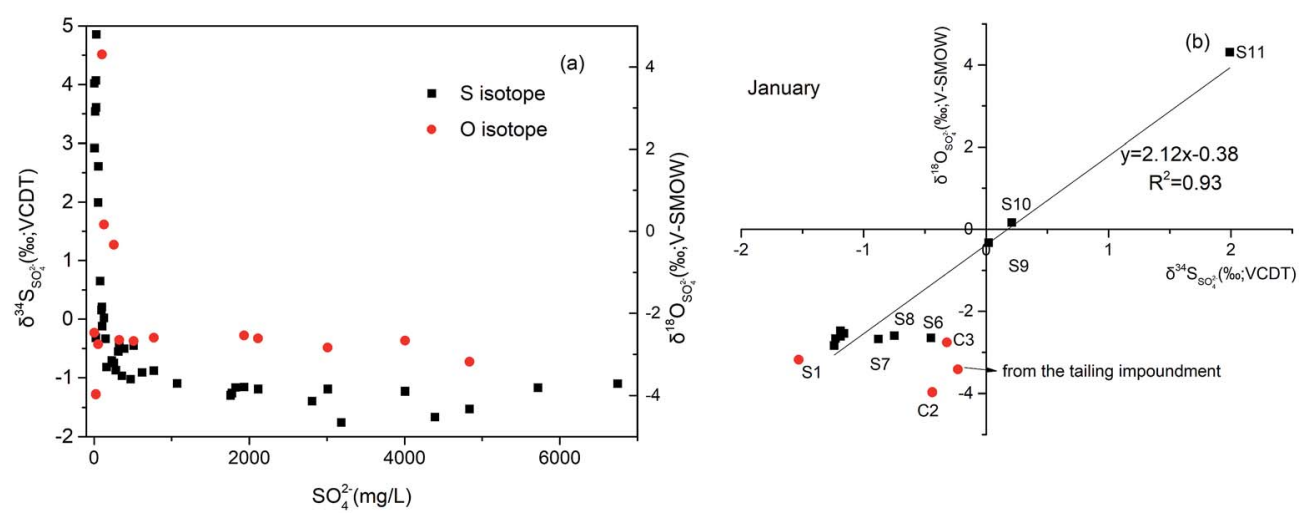

Fig. 7 (a)Variations of $\mathrm{SO}_{4}{ }^{2-}$ concentrations versus $\delta^{34} \mathrm{~S}$ (black dots, in Jan/Aug/Nov) and $\delta^{18} \mathrm{O}$ (red dots, in January) in the Hengshi River. (b) $\delta^{34} \mathrm{~S}$ versus $\delta^{18} \mathrm{O}$ values of dissolved sulfate in surface samples collected in January, and the red dots represent the tributaries.
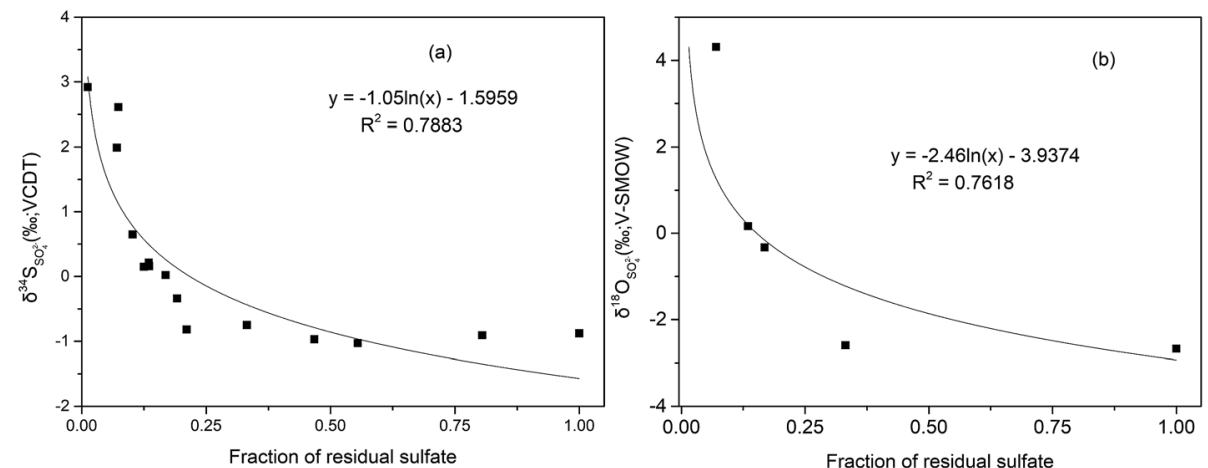

Fig. 8 Cross-plots of the fraction of the residual sulfate to $\delta^{34} \mathrm{~S}$ (collected in Jan/Aug/Nov) and $\delta^{18} \mathrm{O}$ (collected in Jan) sulfate values in samples collected from S7 to S11.

(S0 $\sim$ S8) mainly plot in the lower left-hand quadrant while the samples collected in further downstream move toward the upper right-hand quadrant. In addition, samples collected in C3 also plotted in the lower left-hand quadrant, which means that $\mathrm{C} 3$ cannot be the major $\mathrm{SO}_{4}{ }^{2-}$ source in downstream. It may suggest another important process that affects concentrations and isotope compositions of dissolved sulfate in downstream (after S8): bacterial (dissimilatory) sulfate reduction. From the linear equation fitted with all samples from Hengshi River, the linear regression yielded a correlation coefficient $\left(R^{2}\right)$ of 0.93 and a slope of the regression line of 2.12, which proved that it is bacterial (dissimilatory) sulfate reduction that can modify isotope compositions and concentrations of sulfate along the river. ${ }^{64,65}$ Similar results were reported by our previous study, ${ }^{47}$ and they found that reduced sulfur increased at S7, S8 and S10, which also can prove the existence of BSR.

In order to calculate the average enrichment factors for ${ }^{34} \mathrm{~S}$ and ${ }^{18} \mathrm{O}$ during bacterial sulfate reduction, we use Rayleigh equations $^{64}$ (eqn (4) and (5)) as follows:

$$
\begin{aligned}
\delta^{34} \mathrm{~S}_{\mathrm{SO}_{4}{ }^{2-}} & =\delta^{34} \mathrm{~S}_{\mathrm{SO}_{4}{ }^{2-}-\text { initial }}+\varepsilon \ln f \\
\delta^{18} \mathrm{O}_{\mathrm{SO}_{4}{ }^{2-}} & =\delta^{18} \mathrm{O}_{\mathrm{SO}_{4}{ }^{2-}-\text { initial }}+\varepsilon \ln f
\end{aligned}
$$

where $\varepsilon$ respects the enrichment factor for sulfur and oxygen and $f$ stands for the fraction of residual sulfate in water.

Due to the fact that BSR usually occur in downstream, we can assume that the initial value of $\mathrm{SO}_{4}{ }^{2-}$ concentration $\left(770.46 \mathrm{mg} \mathrm{L}^{-1}\right)$ at $\mathrm{S} 7$ in January as the highest measured sulfate concentration to calculate the fraction of the residual sulfate $\left(f=C_{\mathrm{SO}_{4}{ }^{2-}{ }_{-} \text {measured }} / C_{\mathrm{SO}_{4}{ }^{2-}-\text { initial }}\right)$ from S7 to S11. From these logarithmic functions in Fig. 8, the enrichment factors for sulfur and oxygen were calculated to be $-1.05 \%\left(\varepsilon^{34} \mathrm{~S}\right)$ and $-2.46 \%\left(\varepsilon^{18} \mathrm{O}\right)$, with correlation coefficient $\left(R^{2}\right)$ of 0.79 and 0.76 , respectively. However compared with other study on sulfur isotope enrichment factors for BSR in nature, our $\varepsilon^{34} \mathrm{~S}$ value is relatively low (e.g.: Schroth et al., 2001: $-21.5 \%{ }_{00}{ }^{66}$ Spence et al., 2001: $-9.4 \%{ }_{0}{ }^{67}$ Bolliger et al., 2001: $-23.5 \%$ (ref. 68)), but not unusual (e.g. Mandernack et al., 2000: $-2.6 \%$ (ref. 69)). Similarly, the value of $\varepsilon^{18} \mathrm{O}$ was smaller than that calculated in the study which is $-3.6 \%{ }^{\circ}{ }^{64}$ The low isotope enrichment factors of $\mathrm{S}$ and $\mathrm{O}$ could be attributed to dilution, which can decrease the concentration of $\mathrm{SO}_{4}{ }^{2-}$, then lower the value of fraction of residual sulfate, but have no effect on the values of $\delta^{34} \mathrm{~S}_{\mathrm{SO}_{4}}{ }^{2-}$.

\section{Conclusions}

Mining activities in Dabaoshan Mine area have produced large amount of AMD, characterized by extremely low $\mathrm{pH}$ values 
(2.63-2.98), and high concentrations of heavy metals (e.g. Fe: $>347.78 \mathrm{mg} \mathrm{L}^{-1}$; $\mathrm{Zn}$ : $\left.>96.48 \mathrm{mg} \mathrm{L}^{-1}\right)$ and $\mathrm{SO}_{4}{ }^{2-}(>4008.04 \mathrm{mg}$ $\mathrm{L}^{-1}$ ) which is isotopically depleted in both ${ }^{34} \mathrm{~S}$ and ${ }^{18} \mathrm{O}$. According to the regional distribution of concentrations and isotope ratios of sulfate, sulfide oxidation is the major source in upper stream, followed by precipitating as iron hydroxides (like jarosite, schwertmannite) along the river. Dilution by tributary water (C1 and TP) and precipitation of $\mathrm{SO}_{4}{ }^{2-}$ minerals decreases the concentration of $\mathrm{SO}_{4}{ }^{2-}$, and results in a minimal fractionation on the $\mathrm{S}$ and $\mathrm{O}$ isotope composition on sulfate. On the other hand, the pattern of $\delta^{34} \mathrm{~S}$ of soluble sulfates shows no substantial seasonal variations during the investigation, which indicates that atmospheric deposition through raining also failed to exert an obvious on the $\delta^{34} \mathrm{~S}$ values.

Because of the suitable environment (e.g. neutral $\mathrm{pH}$, and adequate organic materials available) in the downstream, the extent of bacterial sulfate reduction increased gradually in the direction of river flow, which was in consistent with the rapid positive shift in the sulfur and oxygen isotope composition of the dissolved sulfate in the downstream. From the relationship between the fraction of the residual sulfate and the $\delta^{34} \mathrm{~S}$ and $\delta^{18} \mathrm{O}$ values in the downstream (after S7), the enrichment factors for sulfur and oxygen isotope were calculated to be $-1.05 \%$ and $-2.46 \%$, respectively.

In general, $\mathrm{S}$ and $\mathrm{O}$ isotope investigations are found to be useful tools to identify the sources and transformations of sulfur as well as the influence by bacterial sulfate reduction, which will lay a foundation for the remediation strategies of AMD.

\section{Conflicts of interest}

We have read your policy on Conflict of interest and confirm that there are no conflicts to declare.

\section{Acknowledgements}

This work was financially supported by National Natural Science Foundation of China (No.41330639 and 41720104004), the National Key Technology Support Program (No. 2015BAD05B05), and the Guangdong Natural Science Funds for Distinguished Young Scholar (No. 2015A030306005).

\section{References}

1 C. Wisskirchen, B. Dold, K. Friese, J. E. Spangenberg, P. Morgenstern and W. Glaesser, Appl. Geochem., 2010, 25, 1107-1119.

2 M. Edraki, S. Golding, K. Baublys and M. Lawrence, Appl. Geochem., 2005, 20, 789-805.

3 P. Swedlund and J. Webster, Appl. Geochem., 2001, 16, 503511.

4 P. J. Swedlund, J. G. Webster and G. M. Miskelly, Appl. Geochem., 2003, 18, 1671-1689.

5 K. Fukushi and D. A. Sverjensky, Geochim. Cosmochim. Acta, 2007, 71, 1-24.
6 B. K. Saikia, A. C. Dalmora, R. Choudhury, T. Das, S. R. Taffarel and L. F. Silva, Ultrason. Sonochem., 2016, 32, 147.

7 M. Civeira, M. L. S. Oliveira, J. C. Hower, D. M. AgudeloCastañeda, S. R. Taffarel, C. G. Ramos, R. M. Kautzmann and L. F. O. Silva, Environ. Sci. Pollut. Res., 2015, 23, 65356545.

8 M. S. Civeira, C. G. Ramos, M. L. Oliveira, R. M. Kautzmann, S. R. Taffarel, E. C. Teixeira and L. F. Silva, Chemosphere, 2016, 145, 142-147.

9 D. K. Nordstrom and C. N. Alpers, Environmental Geochemistry of Mineral Deposits, 1999, 6, 133-160.

10 S. L. Simpson, S. C. Apte and C. M. Davies, Environ. Chem., 2005, 2, 49-55.

11 M. Gleisner, R. B. Herbert and P. C. F. Kockum, Chem. Geol., 2006, 225, 16-29.

12 D. W. Schindler, R. Wagemann, R. B. Cook, T. Ruszczynski and J. Prokopowich, Int. J. Bifurcation Chaos Appl. Sci. Eng., 1979, 8, 173-178.

13 K. A. Brown, Soil Biol. Biochem., 1985, 17, 39-45.

14 J. W. M. Rudd, C. A. Kelly and A. Furutani, Limnol. Oceanogr., 1986, 31, 1281-1291.

15 M. Koschorreck, FEMS Microbiol. Ecol., 2008, 64, 329-342.

16 P. A. Trudinger, Early Organic Evolution, 1992, pp. 367-377.

17 B. B. Jørgensen, Mccarthy, 1982, 296, 643-645.

18 H. Sass, H. Cypionka and H. D. Babenzien, FEMS Microbiol. Ecol., 1997, 22, 245-255.

19 D. E. Canfield and R. Raiswell, in Taphonomy: Releasing the Data Locked in the Fossil Record, ed. P. A. Allison and D. E. G. Briggs, PlenumPress, 1991, pp. 337-38.

20 R. A. Berner, Am. J. Sci., 1970, 268, 1-23.

21 M. A. Vile and R. K. Wieder, Water, Air, Soil Pollut., 1993, 69, 425-441.

22 A. Fauville, B. Mayer, R. Frommichen, K. Friese and J. Veizer, Chem. Geol., 2004, 204, 325-344.

23 R. S. Thurston, K. W. Mandernack and W. C. Shanks III, Chem. Geol., 2010, 269, 252-261.

24 A. Szynkiewicz, M. Modelska, S. Buczyński, D. M. Borrok and J. P. Merrison, Geochim. Cosmochim. Acta, 2013, 106, 326343.

25 M. Junghans and M. Tichomirowa, Appl. Geochem., 2009, 24, 2034-2050.

26 P. Kroopnick and H. Craig, Science, 1972, 175, 54.

27 R. Seal, Environmental Aspects of Mine Wastes, 2003, vol. 31, pp. 303-334.

28 H. Chiba and H. Sakai, Geochim. Cosmochim. Acta, 1985, 49, 993-1000.

29 A. V. Turchyn, V. Brüchert, T. W. Lyons, G. S. Engel, N. Balci, D. P. Schrag and B. Brunner, Geochim. Cosmochim. Acta, 2010, 74, 2011-2024.

30 K. Knöller, C. Vogt, H. H. Richnow and S. M. Weise, Environ. Sci. Technol., 2006, 40, 3879-3885.

31 B. Brunner, S. M. Bernasconi, J. Kleikemper and M. H. Schroth, Geochim. Cosmochim. Acta, 2005, 69, 47734785 .

32 D. E. Canfield, Geochim. Cosmochim. Acta, 2001, 65, 11171124. 
33 M. E. Böttcher, B. Thamdrup and T. W. Vennemann, Geochim. Cosmochim. Acta, 2001, 65, 1601-1609.

34 B. Brunner and S. M. Bernasconi, Geochim. Cosmochim. Acta, 2005, 69, 4759-4771.

35 P. Zhuang, M. B. Mcbride, H. Xia, N. Li and Z. Li, Sci. Total Environ., 2009, 407, 1551-1561.

36 C. Lin, Y. Wu, W. Lu, A. Chen and Y. Liu, J. Hazard. Mater., 2007, 142, 199-207.

37 A. Chen, C. Lin, W. Lu, Y. Wu, Y. Ma, J. Li and L. Zhu, Chemosphere, 2007, 70, 248-255.

38 F. Yuan and B. Mayer, Chem. Geol., 2012, 291, 13-22.

39 K. Martinello, M. L. Oliveira, F. A. Molossi, C. G. Ramos, E. C. Teixeira, R. M. Kautzmann and L. F. Silva, Sci. Total Environ., 2014, 470-471, 444-452.

40 D. B. K. Saikia, Int. J. Coal Geol., 2014, 121, 26-34.

41 D. Arenas-Lago, F. A. Vega, L. F. O. Silva, M. Lago-Vila and L. Andrade, Fresenius Environ. Bull., 2014, 23, 1025-1035.

42 C. M. N. L. Cutruneo, M. L. S. Oliveira, C. R. Ward, J. C. Hower, I. A. S. D. Brum, C. H. Sampaio, R. M. Kautzmann, S. R. Taffarel, E. C. Teixeira and L. F. O. Silva, Int. J. Coal Geol., 2014, 130, 33-52.

43 F. H. T. Osório, L. F. O. Silva, L. D. S. Piancini, A. C. B. Azevedo, S. Liebel, F. Y. Yamamoto, V. P. Philippi, M. L. S. Oliveira, C. F. Ortolani-Machado and F. F. Neto, Environ. Sci. Pollut. Res. Int., 2014, 21, 9145-9160.

44 H. Zhao, B. Xia, C. Fan, P. Zhao and S. Shen, Sci. Total Environ., 2012, 417, 45-54.

45 P. Zhuang, M. B. McBride, H. Xia, N. Li and Z. Li, Sci. Total Environ., 2009, 407, 1551-1561.

46 J. Liao, Z. Wen, X. Ru, J. Chen, H. Wu and C. Wei, Ecotoxicol. Environ. Saf., 2016, 124, 460-469.

47 M. Chen, G. Lu, C. Guo, C. Yang, J. Wu, W. Huang, N. Yee and Z. Dang, Chemosphere, 2015, 119, 734-743.

48 C. Boukhalfa, Desalination, 2010, 250, 428-432.

49 C. Yang, G. Lu, M. Chen, Y. Xie, C. Guo, J. Reinfelder, X. Yi, H. Wang and Z. Dang, Geoderma, 2016, 281, 21-29.

50 M. E. E. Madden, A. S. Madden, J. D. Rimstidt, S. Zahrai, M. R. Kendall and M. A. Miller, Geochim. Cosmochim. Acta, 2012, 91, 306-321.
51 C. G. Hubbard, S. Black and M. L. Coleman, Chem. Geol., 2009, 265, 321-334.

52 Y. Xie, G. Lu, H. Ye, C. Yang, X. Yi and Z. Dang, J. Environ. Qual., 2017, DOI: 10.2134/jeq2017.03.0122.

53 J. Ribeiro, S. R. Taffarel, C. H. Sampaio, D. Flores and L. F. O. Silva, Int. J. Coal Geol., 2013, 109-110, 15-23.

54 J. Sanchis, D. Bozovic, M. Farre, A. N. Al-Harbi and F. L. Silva, Anal. Bioanal. Chem., 2013, 405, 5915-5923.

55 L. F. O. Silva, F. O. D. Vallejuelo, I. Martinez-Arkarazo, K. Castro, M. L. S. Oliveira, C. H. Sampaio, I. A. S. D. Brum, F. B. D. Leão, S. R. Taffarel and J. M. Madariaga, Sci. Total Environ., 2013, 447, 169-178.

56 C. H. Gammons, T. E. Duaime, S. R. Parker, S. R. Poulson and P. Kennelly, Chem. Geol., 2010, 269, 100-112.

57 T. W. Butler, Appl. Geochem., 2007, 22, 1416-1426.

58 A. Szynkiewicz, D. M. Borrok, G. Skrzypek and M. S. Rearick, Chem. Geol., 2015, 411, 323-335.

59 M. L. W. Tuttle, G. N. Breit and I. M. Cozzarelli, Chem. Geol., 2009, 265, 455-467.

60 A. V. Turchyn, E. T. Tipper, A. Galy, J.-K. Lo and M. J. Bickle, Earth Planet. Sci. Lett., 2013, 374, 36-46.

61 C. H. Gammons, A. Brown, S. R. Poulson and T. H. Henderson, Appl. Geochem., 2013, 31, 228-238.

62 G. Antler, A. V. Turchyn, V. Rennie, B. Herut and O. Sivan, Geochim. Cosmochim. Acta, 2013, 118, 98-117.

63 R. Frömmichen, S. Kellner and K. Friese, Environ. Sci. Technol., 2003, 37, 1414-1421.

64 K. Knoller, A. Fauville, B. Mayer, G. Strauch, K. Friese and J. Veizer, Chem. Geol., 2004, 204, 303-323.

65 X. Li, Y. Gan, A. Zhou, Y. Liu and D. Wang, Appl. Geochem., 2013, 35, 99-109.

66 M. H. Schroth, J. Kleikemper, C. Bolliger, S. M. Bernasconi and J. Zeyer, J. Contam. Hydrol., 2001, 51, 179-195.

67 M. J. Spence, S. H. Bottrell, S. F. Thornton and D. N. Lerner, J. Contam. Hydrol., 2001, 53, 285-304.

68 C. Bolliger, M. H. Schroth, S. M. Bernasconi, J. Kleikemper and J. Zeyer, Geochim. Cosmochim. Acta, 2001, 65, 3289-3298.

69 K. W. Mandernack, L. Lynch, H. R. Krouse and M. D. Morgan, Geochim. Cosmochim. Acta, 2000, 64, 39493964. 